\title{
上顎癌関連抗原の推定分子量とその局在
}

\author{
山内 進* ・加藤 和夫** 小 小松 信行 \\ 斉藤 成明 ・堀内 正敏 ・三宅 浩郷
}

\section{An Estimation of the Molecular Weight and \\ Location of Maxillary Cancer Associated Antigen}

\author{
Susumu Yamauchi, Nobuyuki Komatsu, Shigeaki Saitoh, \\ Masatoshi Horiuchi and Hirosato Miyake \\ (Tokai University) \\ Kazuo Katoh \\ (Nippon Kayaku Co., LTD)
}

It is well known that the early diagnosis of maxillary cancer (MC) is very difficult on the basis of its clinical appearance and symptoms, since nasal obstraction, bloody discharge, toothache and loosening of the teeth are common in the early stage.

A new technique was devised for the isolation and charactrization of maxillary cancer associated antigens (MCAA), since elucidation of MCAA has been one of the major achievements of tumor immunology.

Frozen sections of MC $10 \mu \mathrm{m}$ thick were applied directly to PAG-plates for isoelectric focusing. Saline extract of tumor tissues and sera were treated in the same manner.

Specific components at around $\mathrm{pH} 6.1$ were determined on PAG-plates and collected by chromatofocusing. Anti-MCAA rabbit serum was obtained by immunization with the components around $\mathrm{pH} 6.1$ and anti-MCAA IgG serum was purified by protein A sepharose CL-4B.

The purpose of this study was to demonstrate the location of MCAA in tumor sections and determine its approximate molecular weight. Tissues of 10 out of 11 $(91 \%)$ cases of MC were stained positively by indirect immunofluorescence and immunoperoxidase techniques. This definitely positive staining was demonstrated on the cell membranes of $\mathrm{MC}$, while in 8 control cases (normal maxillary sinus membrane, paratine tonsil, parotid gland and membranes from patients with chronic paranasal sinusitis) the staining was definitively negative.

The molecular weight of MCAA was investigated by SDS-PAG and ImmuneBlotting. The former showed two components (170k-225k), and the latter detected two components (120k-136k) and one minor component of $76 \mathrm{k}$.

Key words : maxillary cancer associated antigens (MCAA), isoelectric focusing (IF), Immune-Blotting (IB) 


\section{緒言}

近年, C E AやAF P あるいは, H C G や H P Lの如き癌胎児性蛋白や癌胎盤性蛋白が担癌 に随伴してみられることから，癌の診断や治療 効果の判定に利用されているが(1) 4)，これらの 蛋白の中には癌以外の疾患にも検出され，また 微量測定法の開発により正常組織にも微量なが

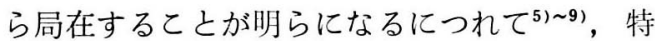
定の癌に特異的抗原あるいは関連抗原老検出す る方法が期待されている，

著者らは，とのような視点から，上顎癌（M C) の早期発見と免疫学的治療への忘用をめざ し, 上顎癌関連抗原 (MCAA) の分離之分取 に関し，新たな technique を開発し，特異 性の高い抗 MCAA 抗体の作製を企図した。

MCAA の分離, 分取法および家嵬への免疫に よって得られた抗体の精製之その特異性に関し てはすでに報告している(10).

木稿では, chromatofocusing 法により分取 された MCAAの推定分子量および上顎癌組 織における MCAA の局在部位と陽性率に関 し，负疫組織学的に検索したので報告する.

\section{材料と方法}

\section{1）分子量の測定}

分子量の测定に関しては, 3 例の上顎癌組織 を材料に，Davies ${ }^{11}$ の方法で得られた crude な抽出液を chromatocusing (CF) (Pharmasia, Sweden）法によりpH6前後で分取し， 限外沂過にて濃縮したものを用いた。

それぞれの抽出液（No.2，3，4）は，7.5\% SDS-Polyacrylamide Gel (SDS-PAG)で泳 動後, Nitrocellulose (NC) 膜 (Bio-Rad 社, U.S.A）に電気的に transfer し, 一次抗体 には抗 MCAA IgG 抗体を用い, ImmunoBlotting (IB) 法"2)を採用した.

分子量の推定は, IBGel 之並走した Marker Proteins（オリエンタル酵母 K.K.）の SDSPAGE 後 Silver 染色 (Bio-Rad 社, U.S.A) により出現したバンドの位置から得た標準曲線 によって算定した
2）上顎癌関連抗原の組織局在と陽性率

a ) 被検対象 :

上䫴扁平上皮癌11例, 対照組織には, 慢性副 鼻腔炎粘膜 4 例, 正常上顎洞粘膜 1 例, 口蓋扁 桃 2 例および耳下腺 1 例を用いた。

b ）上顎癌関連抗原の組織局在の証朋法： 検索は間接蛍光抗体法（ＩＩＦ）および間接

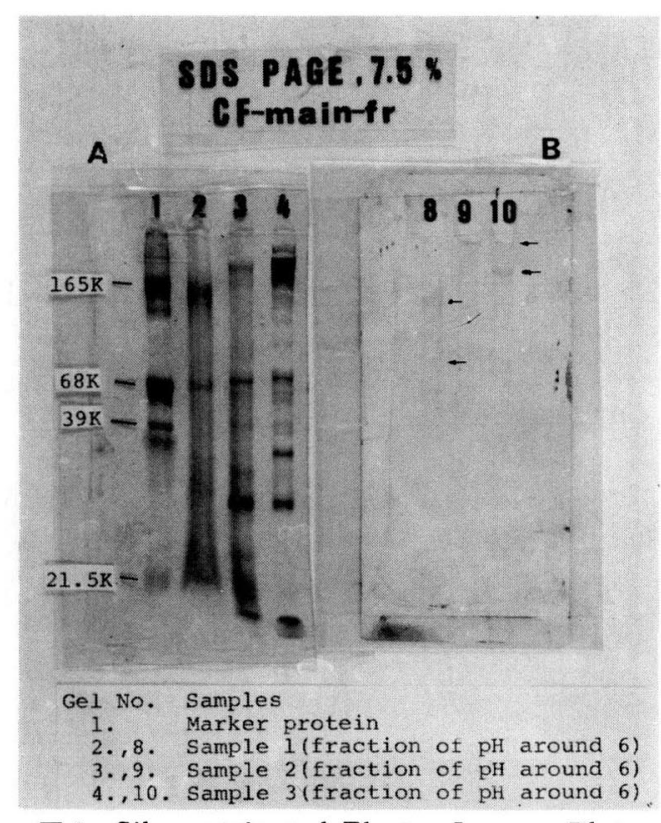

図 I Silver stain and Electro-Immuno-Blot

MW-Determination

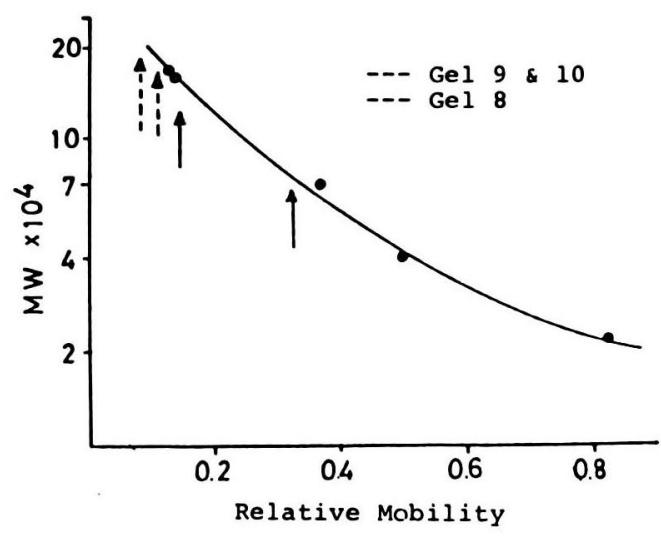

図 2 MW Determination 
酵素抗体法（I P O）により行われた. 即ち, 各被検組織は $4 \mu \mathrm{m}$ 程度の凍結連続切片標本上 し， 1 検体につき 2 枚の標本が準備された.

固定は I I F 用に $4{ }^{\circ} \mathrm{C}$ の純アセトンで20分, I PO用には $4{ }^{\circ} \mathrm{C}$ で $4 \%$ Periodate-lysineparaformaldehyde (PLP) で 30 分の処理を

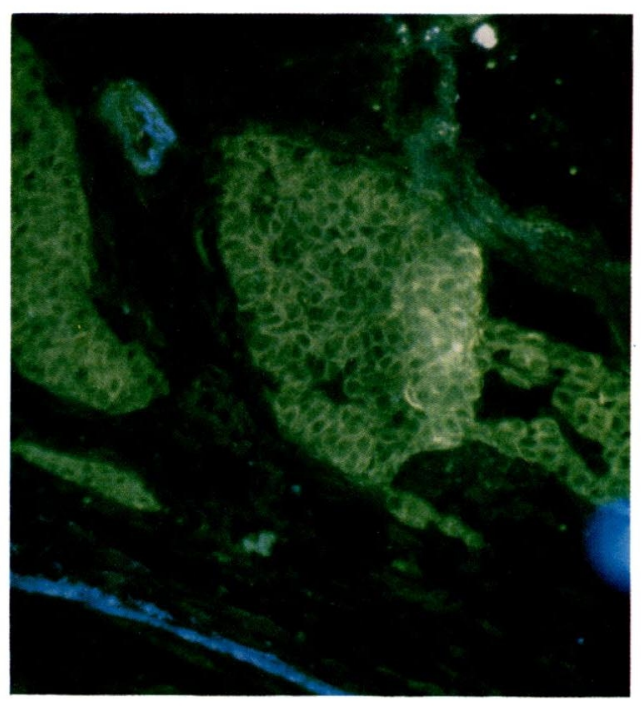

行った.

一次抗体には, I I F, I PO共に抗MCAA IgG 抗体を 1：40亿稀釈し, 二次抗体はFITC 標識抗ウサギ $\operatorname{IgGF}\left(\mathrm{ab}^{\prime}\right)_{2}$ ヤギ血清 (Capple 社, U.S.A）およびH R P 標識抗ウサギ IgGF $(\mathrm{ab})_{2}$ ヤギ血清（Capple 社，U.S.A）をそれぞ

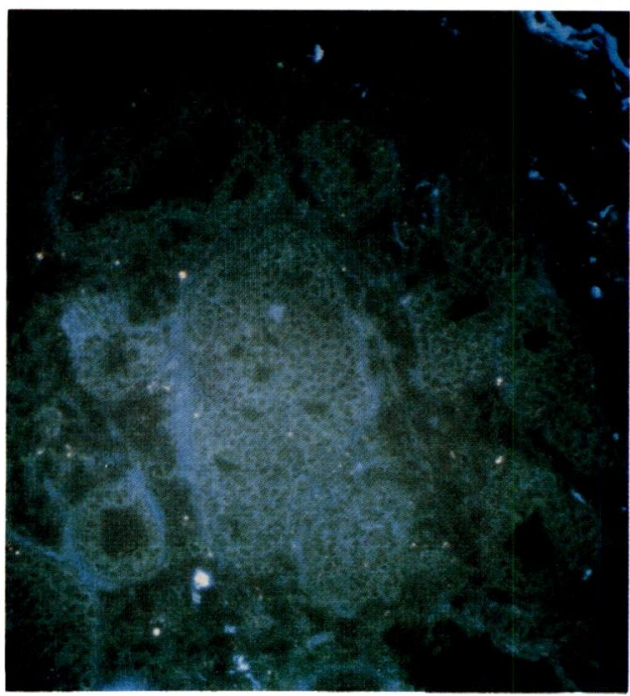

図 3 Specific flourescence for MCAA was demonstrated on the surface of cancer cells. IIF staining of control was negative. $(L: \times 200, R: \times 100)$
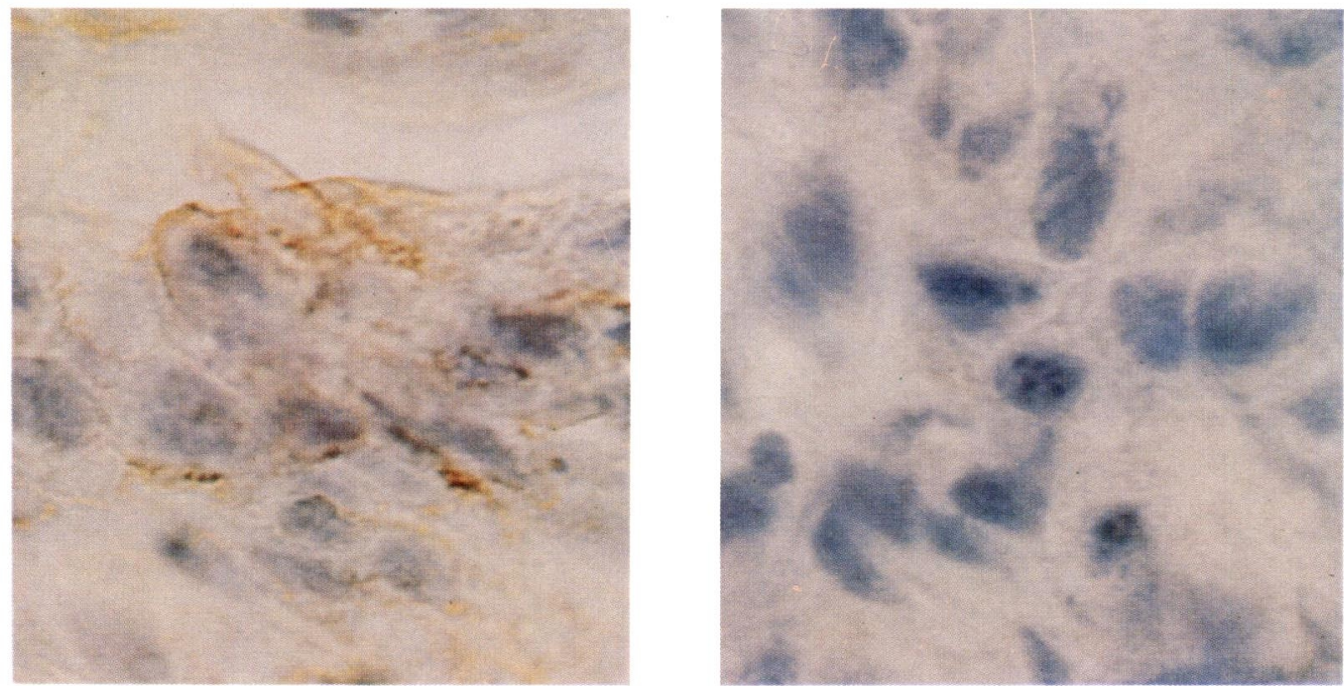

図 4 The presence of MCAA was detectable on the cell surface of MC by indirect $\mathrm{PO}$ reaction. No peroxydase reactive products were demonstrated in control. ( $\mathrm{L}: \times 1000, \mathrm{R}: \times 1000)$ 
れ $1: 40$ と $1: 60$ 稀釈倍数で用い, H R Pの 呈色反応には，0.05\%過酸化水素加3.3-Diaminobenzidine $(\mathrm{DAB})$ 液老用いた。

一方，対照には，一次抗体の代りに，非免疫 ウサギ IgG 血清を 1：40に稀釈したものを使 用した。

\section{結果}

1) 上顎癌関連抗原の推定分子量

SDS-PAGE 後 Silver 染色により出現し たバンドは, 図 1 - A に示し, I B 法による特 異的免疫化学反応の結果生じたバンドは図 1 Bに矢印で示した。

Marker Proteins による標準曲線（図 2) 加ら算定された推定分子量は, $170 \mathrm{~K}$ - $225 \mathrm{~K} の$ 間に 2 成分， $120 \mathrm{~K}-136 \mathrm{~K}$ の間に 2 成分，また
約76Kに minor な 1 成分が得られた。

2）上顎癌関連抗原の組織局在と陽性率

I I F 法による MCAAの局在を示したつが 図3である.

抗 MCAA IgG 抗体によって認識された MCAA は，上顎癌細胞膜上に明膫な陽性像と して鑑察されるが，間質等では陰性の所見が示 されている。一方，対照である非免疫ウサギ IgG 血清による上顎癌組織との反応では，明 らかな㓌性像が得られた。

I PO法による結果を示したのが図 4 であ る. MCAA の局在性とその程度に応じて, 癌 細胞膜上にドット状や線状を呈する陽性反応が みられている，一方非免疫ウサギ IgG 血清と の反応による対照試験では陰性である.

表 I. Results of Maxillary cancer and controls by using indirect immunoflourescence (IIF) and immunoperoxydase (IPO)

\begin{tabular}{c|c|c|c|c|c}
\hline Case No. & Subjects & Histological diag. & IIF & IPO & Decision \\
\hline 1 & Maxillary Ca & S.C.C & + & + & + \\
2 & Maxillary Ca & S.C.C & + & + \\
3 & Maxillary Ca & S.C.C & + & + & + \\
4 & Maxillary Ca & S.C.C & + & + \\
5 & Maxillary Ca & S.C.C & + & + \\
6 & Maxillary Ca & S.C.C & + & + \\
7 & Maxillary Ca & S.C.C & + & + \\
8 & Maxillary Ca & S.C.C & + & + \\
9 & Maxillary Ca & S.C.C & + & + \\
10 & Maxillary Ca & S.C.C & + & + \\
\end{tabular}

Percent of positive : $91 \%$

Unrelated MC as controls

1 Membrane of maxillary sinus

2 Palatine tonsil

3 Palatine tonsil

4 Parotid

5 Membrane of chronic paranasal sinusitis

6 Membrane of chronic paranasal sinusitis

7 Membrane of chronic paranasal sinusitis

8 Membrane of chronic paranasal sinusitis 
上顎扁平上皮癌組織11例抢よび，その他の各 種組織 8 例に関する成績を表 1 亿緾めた. No.8 の症例は陰性と判定されたので，上顎癌に対す る総括的陽性率は $91 \%$ となる。

\section{考察}

上顎癌では，腫瘍に特異的な初期症状に乏し く, 主訴は鼻閉や歯痛といった一般的症状が多 いことから早期診断が困難とされ，また癌の発 生部位が顔面であることから外見上悲惨な状態 を呈することが多く，早期発見が強く望まれて いる.

著者らはこれまで，上顎癌の腫瘍 Marker として，C E AやAF P，あるいはH C GやH PLを組織 level での局在や血清 level で の検索を試み上顎癌に㧊いても，乙れらの癌胎 児性蛋白や癌胎般性蛋白が検出されることを報 告して来たが ${ }^{13) 14)}$ ，上顎癌の早期診断や特異性 に関する parameter としての価值には疑問 がある.

腫瘍免疫の研究に際し, 最も重要な基礎作業 の 1 つは, 腫瘍特異抗原や腫瘍関連抗原の分離 や分取であろう。

何らかの方法で，乙机らの抗原を分取出来れ ば抗体の作製は可能であり，また特定の腫瘍に 特異性の高い抗体が得られれば，早期診断や再 発の早期探知のための種々の technique の開 発が期待される.

著者らは, この研究に際し, 最初に試みたこ 上は従来の方法と全く異った癌関連抗原分離法 を開発し, MCAA を分取し, 家克を免疫し, 特異性の高い抗 MCAA 抗体を作ることであ った. 上述した如く, 著者らが考案した方法に より作製した抗 MCAA IgG 抗体によって認 識された MCAA は，上顎癌細胞膜上に局在 することは朋らかで，しかも全ての腫瘍細胞が 常に一様に陽性反応を呈するのではなく, MC $\mathrm{AA}$ の発現や局在の程度に応じて陽性像も多 彩である. 上顎癌の進展や浸潤の様相は, 連続 的に観察すると，あたかも称じれドーナツ状资 呈しているものが多く興味深い.
抗 MCAA IgG 抗体による上顎扁平上皮癌 の平均陽性率は，91\%であったととから，今後 上顎癌の早期診断への応用が期待される。さ て, MCAA の推定分子量の测定に際し, C F によって分取された分画は, $\mathrm{pH} 6$ 前後のもので あるが, 本法は, ゲル沪過により分子量の違い から分画される徒来の方法と異なり，物質の pHの差にもとづき分離されるもので, $\mathrm{pH} 0.02$ の幅で分離が可能な, 今日最む分離能に優れた 方法である.

pH6 前後で分取された各サンプルは, SDS一 PAGE の後 Silver 染色により多数のバンド が出現したが，抗 MCAA IgG 抗体はNC膜 に転写された MCAA を認識し，その位置は 複数のバンドとして示された. このととは，I I FやI PO法で上顎癌細胞膜上に証明された MCAA は単一のあのでないてとを示している.

著者らは，乙れまでの成績にもとづき，今後 MCAA を YMN抗原（山内, 三宅, 日本化薬 のイニシャルをとり）と命名し，またての抗原 により作製した抗体を $\mathrm{YMN}$ 抗体とよぶことに した.

\section{結語}

著者らは，上顎癌の早期彰断と治療への忍用 をめざして，特異性の高い抗体を作製せんと し，新しく腫瘍関連抗原の分離法を開発し，上 顎癌関連抗原を分取し，家鬼免疫して抗 $M$ CAA IgG 抗体を作製し，精製した。

今回は，乙の抗 MCAA IgG 抗体を用いて 次の点を明らかにした。即ち,

1) SDS-PAG および Immuno-Blotting 法により推定分子量が求められた.

2 ）推定分子量は, $170 \mathrm{~K}-225 \mathrm{~K}$ の間に 2 成 分， $120 \mathrm{~K}-136 \mathrm{~K}$ の間に 2 成分および約 $76 \mathrm{~K}$ に minor な 1 成分が得られた。

3) 抗 MCAA IgG 抗体によって認識され た. MCAA は I I FやI PO法により上顎癌 細胞膜上に局在することが明らかにされた。

4 ）上䕱癌以外の各種組織では，全例に $M$ CAA は検出されなかった。 
5 ）上顎扁平上皮癌11例に対し，MCAA は 10例に検出され，陽性率91\%であった。

稿を終るに臨み，本研究の技術面で御協力をいただ いた耳鼻咽喉科学教室の四十万均技術員に深謝の意を 表します。

本論文の要旨は, 第 85 回日本耳鼻咽喉科学会総会 （1984，東京）における宿題報告「上顎癌をめぐる諸 問題」の中で三宅浩郷教授によって演述された。な お, 本研究の一部は文部省科学研究費によるものであ るととを記し，感謝の意を表します。

\section{文献}

1) Gold P and Freedman SO : Demostration of tumor specific antigens in human colon carcinoma by immunological tolerance and absorption techniques. J Exp Med |2| : 439 $\sim 462,1965$.

2) Tatarinov YS: Presence of embryonal $\alpha$ globulin in the serum of patients with primary hepatocellular carcinoma. Vopr Med Khim (USSR) 10:90 91, 1964.

3 ) Hussa RO: Human chorionic gonadotropin, a clinical marker : Review of its biosynthesis. The Ligand Review 2 Suppl $2: 1$, 1981.

4) Sammaan NA, Smith JP and Rutledge FN : The significance of measurement of human placental lactogen, human chorionic gonadotro pin and carcinoembryonic antigen in patient with ovarian carcinoma. Am J Obstet Gynecol I26: 186 189, 1976.

5) Goldenberg DM, Sharkey RM and Primus $\mathrm{FJ}$ : Carcinoembryonic antigen in histopathology : Immunoperoxidase staining of conventional tissue sections. J Nath Cancer Inst $57: 11 \sim 22,1976$.
6) von Kleist S, Chavanel G and Burtin P : Identification of antigen from normal human tissue that crossreacts with the carcinoembryonic antigen. Proc Natl Acad Sci USA $69:$ 2492 2494, 1972

7 ) Endo Y : Clinical significance of $\alpha$-fetoprotein in hepatitis and liver cirrhosis. Ann NY Acad Sci $259:$ 234 238, 1975.

8) Gitlin D : Normal biology of $\alpha$-fetoprotein. Ann NY Acad Sci 259: $7 \sim 12,1975$.

9) Braunstein GD, Kamdar V, Rasor J, Swaminathan $\mathrm{N}$ and Wade $\mathrm{ME}$ : Widespread distribution of chorionic gonadotropin like substance in normal human tissue. $\mathrm{J}$ Clin Endocrinol Metab 49: 917〜925, 1979.

10）山内 進, 斉藤成明, 小松信行, 三宅浩郷：上顎 癌細胞より分難された腫瘍関連抗原. 耳鼻臨床 78 : 2875 2882, 1985.

11) Davies DAL : Mouse histocompatibility isoantigens derived from normal and from tumor cells. Immunology II : 115 125, 1966 .

12) Towbin H, Staehlin $T$ and Gordon $J$ : Electrophoretic transfer of proteins from polyacrylamide gels to nitrocellulose sheets: Procedure and some applications. Proc Natl Acad Sci USA 76:4350 4354, 1979.

13）山内 進, 小沢 敦, 小松信行, 斉藤成明, 三宅 浩郷：上䫈癌患者における免疫学的研究. 第 2 報, 癌胎児性および癌胎艋性蛋白の検索. 第10回 日本臨床免疫学会総会, p 201, 1982.

14）三宅浩郷：上靧癌をめぐる諸問題. 第85回日本耳 鼻咽喉科学総会宿題報告. 147〜 157頁, 港北出版, 東京, 1984 .

$$
\begin{aligned}
& \text { 原稿到着: 昭和 } 60 \text { 年 } 7 \text { 月 } 26 \text { 日 } \\
& \text { 別刷請求先 : 山内 進 } \\
& \text { 于259-11 伊勢原市望星台 } \\
& \text { 東海大学医学部共利研微生物 }
\end{aligned}
$$

